Abstracta Iranica

Revue bibliographique pour le domaine irano-aryen

Volume 32-33 | 2013

Comptes rendus des publications de 2009-2010

\title{
Stefan Zawadzki. A Document Concerning the Sale of an Ass from Persian Sippar
}

\section{Astrid Nunn}

\section{(2) OpenEdition}

1 Journals

Édition électronique

URL : http://journals.openedition.org/abstractairanica/40445

DOI : 10.4000/abstractairanica.40445

ISSN : 1961-960X

\section{Éditeur :}

CNRS (UMR 7528 Mondes iraniens et indiens), Éditions de l'IFRI

\section{Édition imprimée}

Date de publication : 1 décembre 2013

ISSN : 0240-8910

\section{Référence électronique}

Astrid Nunn, "Stefan Zawadzki. A Document Concerning the Sale of an Ass from Persian Sippar », Abstracta Iranica [En ligne], Volume 32-33 | 2013, document 133, mis en ligne le 01 juillet 2016, consulté le 28 septembre 2020. URL : http://journals.openedition.org/abstractairanica/40445 ; DOI : https://doi.org/10.4000/abstractairanica.40445

Ce document a été généré automatiquement le 28 septembre 2020.

Tous droits réservés 


\title{
Stefan Zawadzki. A Document Concerning the Sale of an Ass from Persian Sippar
}

\author{
Astrid Nunn
}

\section{RÉFÉRENCE}

Stefan Zawadzki. «A Document Concerning the Sale of an Ass from Persian Sippar ». KASKAL 6, 2009, p. 215-222.

1 La tablette en question, qui appartient au British Museum, est un contrat de vente d'un âne. Elle date de la 36ème année de Darius I. Elle est publiée en détail car les ventes d'ânes sont rares. Curieusement, le prix des ânes augmente sensiblement à partir de Nabonide et le nombre de leur vente croît avec l'époque achéménide. La cause de cette croissance n'est pas élucidée.

\section{AUTEURS}

\section{ASTRID NUNN}

Université de Munich 